\title{
Natural host-range and experimental transmission of Laem-Singh virus (LSNV)
}

\author{
T. Sathish Kumar ${ }^{1}$, P. Krishnan ${ }^{2}$, M. Makesh ${ }^{1}$, A. Chaudhari ${ }^{1}$, C. S. Purushothaman ${ }^{1}$, \\ K. V. Rajendran ${ }^{1, *}$ \\ ${ }^{1}$ Central Institute of Fisheries Education (CIFE), Panch Marg, Off Yari Road, Versova, Andheri (W), Mumbai 400061, India \\ ${ }^{2}$ Central Agricultural Research Institute, Port Blair, Andaman \& Nicobar Islands 744101, India
}

\begin{abstract}
Slow growth caused by viral diseases has become a major constraint in shrimp aquaculture. Laem-Singh virus (LSNV), a positive-sense single-stranded RNA (ssRNA) virus, has been identified in Penaeus monodon showing slow growth syndrome. To examine the host-range and transmission modes of the virus, 6 species of penaeid shrimp of varying life stages, sourced from the wild and from farms, as well as juvenile mud crabs Scylla serrata, were screened using RT-nested PCR. LSNV was detected in P. monodon, Fenneropenaeus merguiensis, Metapenaeus dobsoni, and Litopenaeus vannamei, but not in F. indicus, Marsupenaeus japonicus or S. serrata. LSNV was most prevalent in P. monodon followed by M. dobsoni, F. merguiensis, and L. vannamei, and real-time quantitative RT-PCR (qRT-PCR) showed that LSNV infection loads were highest in P. monodon, followed by L. vannamei, M. dobsoni, and F. merguiensis. The nucleotide sequence of the LSNV RdRP gene fragment amplified by RT-nested PCR was highly conserved (99\% identity) across these 4 penaeid species. LSNV was detected in both small and normal-sized P. monodon collected from the same pond. In experimental infections of both $P$. monodon and $S$. serrata, LSNV infection loads increased over time. The present study extends the known natural penaeid host-range and geographical distribution of LSNV and shows for the first time the potential susceptibility of $S$. serrata.
\end{abstract}

KEY WORDS: Laem-Singh virus $(\mathrm{LSNV}) \cdot$ Penaeid shrimp $\cdot$ Penaeus monodon $\cdot$ PCR $\cdot$ Real-time $\mathrm{PCR} \cdot$ Host-range $\cdot$ Experimental transmission

Resale or republication not permitted without written consent of the publisher

\section{INTRODUCTION}

Viral disease outbreaks have been increasing in penaeid shrimp aquaculture, and the number of viral pathogens has increased to more than 20 (Lightner 1996, Loh et al.1997, Lightner \& Redman 1998, Umesha et al. 2008). Of several diseases of unknown or obscure aetiology that have emerged recently, monodon slow growth syndrome (MSGS) has been significant in hampering production yields of Penaeus monodon, particularly in Thailand where it was first reported (Chayaburakul et al. 2004). A similar condition has also been reported in P. monodon farmed in East Africa (Anantasomboon et al. 2006).
Investigations of MSGS-affected Penaeus monodon in Thailand identified a new virus that was named LaemSingh virus (LSNV) after the name of the province where it was first identified (Sritunyalucksana et al. 2006). LSNV infection also occurs in P. monodon displaying no overt signs of MSGS, and experimental infections have identified no direct correlation between infection and slow growth (Anantasomboon et al. 2006, Sritunyalucksana et al. 2006). However, as LSNV is associated with retinopathy in slow growing P. monodon, it is believed to be a contributing factor to slow growth.

LSNV contains a positive-sense, single-stranded RNA genome, forms 25 to $30 \mathrm{~nm}$ diameter icosohedral particles, and is related genetically to insect-transmit- 
ted plant viruses in the family Luteoviridae (Sritunyalucksana et al. 2006, Sittidilokratna et al. 2009). The natural host-range of LSNV is presently unknown, but it occurs commonly in Penaeus monodon, and limited studies have suggested a geographical distribution restricted to south and southeast Asia (Sittidilokratna et al. 2009). It has also been detected in Litopenaeus vannamei in Thailand affected by abdominal segment deformity disease (Sakaew et al. 2008), suggesting that its natural host-range might include species other than $P$. monodon. There is limited evidence of LSNV occurring in $P$. monodon cultured in India (Prakasha et al. 2007, Rai et al. 2009), but it has not been associated with slow growth, and the virus has not been reported from any other crustaceans. Given this background, the natural host-range of LSNV was investigated for selected crustaceans present in India together with the potential for mud crabs to be a carrier of the virus.

\section{MATERIALS AND METHODS}

Samples. The commercially important penaeid shrimp species Penaeus monodon, Fenneropenaeus merguiensis, F. indicus, Marsupenaeus japonicus, Litopenaeus vannamei, Metapenaeus dobsoni, and the mud crab Scylla serrata were sampled. Tissue samples were collected from wild and cultured shrimp at postlarvae/juvenile/brooder stages or were supplied preserved in RNAlater (Ambion).

Overtly normal and slow-growing juvenile farmed Penaeus monodon originated from Pancham Aqua Farm, Safale, Maharashtra, India. Fenneropenaeus merguiensis and $F$. indicus postlarvae and juveniles originated from a hatchery and farm in Tamil Nadu, India. Juvenile Marsupenaeus japonoicus originated from a farm in Tamil Nadu, and juvenile wild Metapenaeus dobsoni were sampled from the Chennai coast of Tamil Nadu. L. vannamei postlarvae and juveniles originated from a hatchery and farm in Andhra Pradesh, and juvenile mud crabs were collected from Maharashtra. Pleopods collected from the 20 wildcaught $P$. monodon brooders from the Andaman Sea were preserved in RNAlater and transported to the laboratory. For LSNV transmission experiments, live shrimp were maintained in $500 \mathrm{l}$ tanks containing seawater at $24 \%$ salinity. The ambient water temperature was 25 to $30^{\circ} \mathrm{C}$. Mud crabs were maintained in rectangular plastic tanks with wet mud as a bottom substrate. Shrimp were fed commercial feed pellets twice daily, and crabs were fed chopped mussel meat.

Tissue collection. Crustaceans were anesthetised on ice before sampling gill, pleopod, hepatopancreas, lymphoid organ, stomach, heart, nerve cord, brain, and optical lobe tissues using sterile scissors. To avoid cross-contamination, dissecting instruments were flamesterilized between individuals. RNA was extracted from tissues immediately after their collection. RNA was also extracted from tissues and whole postlarvae preserved in RNAlater soon after these were received at the laboratory.

Experimental infection. Penaeus monodon that tested RT-PCR-positive for LSNV were used to prepare a viral inoculum. Tissues such as gill, pleopod, and lymphoid organ were dissected aseptically, homogenized in sterile PBS using a mortar and pestle. The homogenate was centrifuged at $2432 \times g$ for $20 \mathrm{~min}$ at $4^{\circ} \mathrm{C}$ to remove tissue debris, and the supernatant was filtered through a $0.22 \mu \mathrm{m}$ membrane filter fitted to a syringe. Aliquots of the filtrate were stored at $-80^{\circ} \mathrm{C}$ until used. RNA extracted from an inoculum aliquot was tested by RT-PCR to confirm the presence of LSNV RNA. Aliquots (100 $\mu \mathrm{l})$ of inoculum were injected intramuscularly into the third abdominal segment of healthy shrimp, which had tested RT-PCR-negative for LSNV, or into the coxa of the swimming leg of mud crabs using a $1 \mathrm{ml}$ syringe fitted with a 26 -gauge needle. Injected animals were maintained as described earlier and were sacrificed at different times postinjection to collect tissue for RT-PCR analysis.

Total RNA extraction. Dissected tissues were placed into screw-cap tubes containing glass beads and $750 \mu \mathrm{l}$ TRIzol (Invitrogen). The tissues were homogenized at $4000 \mathrm{rpm}$ for $20 \mathrm{~s}$ in a Micro Smash MS-200 (TOMY), and total RNA was extracted according to the manufacturer's protocol. The RNA pellet was resuspended in $25 \mu \mathrm{l}$ nuclease-free water, an aliquot quantified using a NanoDrop 2000 spectrophotometer (Thermo Scientific) and stored at $-80^{\circ} \mathrm{C}$.

cDNA synthesis. cDNA was synthesized using Superscript ${ }^{\mathrm{TM}}$ II (Invitrogen) as per the manufacturer's protocol. Briefly, $1.0 \mu \mathrm{g}$ total RNA was reverse-transcribed in a $10 \mu \mathrm{l}$ reaction containing $100 \mu \mathrm{M}$ random hexamers, $10 \mathrm{mM}$ each dNTP (Fermentas), $200 \mathrm{U}$ of Superscript $^{\mathrm{TM}}$ II reverse-transcriptase and reaction buffer containing $250 \mathrm{mM}$ Tris- $\mathrm{HCl}(\mathrm{pH} 8.3), 250 \mathrm{mM}$ $\mathrm{KCl}, 20 \mathrm{mM} \mathrm{MgCl}_{2}$, and $50 \mathrm{mM}$ dithiothreitol (DTT). cDNA was stored at $-20^{\circ} \mathrm{C}$ until use.

PCR. RT-nested PCR was performed with 2 sets of LSNV-specific PCR primers, using reaction components and cycling conditions as reported by Sittidilokratna et al. (2009). Briefly, $2.0 \mu \mathrm{l}$ cDNA (200 ng RNA equivalents) was amplified in a $25 \mu \mathrm{l}$ reaction volume in the first-step PCR, and $2.0 \mu \mathrm{l}$ of this PCR was used as the template in a $25 \mu \mathrm{l}$ nested PCR. After thermal cycling in an Applied Biosystems instrument, an aliquot of each PCR was resolved in $2 \%$ agarose-Trisacetate-EDTA (TAE) gels containing $0.5 \mathrm{\mu g} \mathrm{ml}^{-1}$ ethidium bromide alongside a 100 bp DNA marker (Fermentas), and amplified DNA was visualized under UV 
illumination using a gel documentation system (DNr Bio-imaging Systems).

Real-time RT-PCR. A 205 bp LSNV PCR product was cloned into $\mathrm{pTZ}$ 57R/T vector (Fermentas) and plasmid DNA was purified and then quantified using a NanoDrop 2000 spectrophotometer. The DNA copy number was calculated from the DNA concentration and the molecular mass of the plasmid DNA containing the 205 bp LSNV insert. Based on this calculation, plasmid DNA was serially diluted (1:10) from $1 \times 10^{9}$ DNA copies to 1 DNA copy. LSNV RNA copy numbers in clinical samples, after conversion to cDNA (assuming equivalence of RNA and cDNA) were quantified by extrapolating from the standard curve generated using the plasmid DNA dilution series. Real-time qRT-PCRs $(25 \mu \mathrm{l})$ contained $12.5 \mu \mathrm{l} \mathrm{Maxima}{ }^{\mathrm{TM}}$ SYBR Green qPCR Master Mix (Fermentas), $0.5 \mu \mathrm{l}(0.9 \mu \mathrm{M})$ of each primer (LSNVQPF1: 5'-TAG CCT GCG GTG ATG ACA CTA3'; LSNVQPR1: 5'-GCT TGC GAT CGA CAC TCT TAA C-3'), and $2 \mu$ (equivalent to $200 \mathrm{ng}$ ) cDNA. Thermal cycling employed the ABI 7500 Real-time PCR system (Applied Biosystems). The thermal cycling profile used was $95^{\circ} \mathrm{C}$ for $10 \mathrm{~min}$, followed by 40 cycles of $95^{\circ} \mathrm{C}$ for $15 \mathrm{~s}$, and $60^{\circ} \mathrm{C}$ for $1 \mathrm{~min}$. Melting curve analysis of amplified DNA products was performed at the end of each PCR to confirm amplicon specificity. For each cDNA, 3 well replicates were used.

Statistical analysis. Analysis of variance to determine the significance of variation between uninfected and LSNV-infected shrimp and production traits such as body length and weight used the PROC GLM program (SAS 2010).

\section{RESULTS}

\section{RT-PCR detection of LSNV in Penaeus monodon}

A 2-step LSNV RT-PCR amplified 357 bp primary and $205 \mathrm{bp}$ nested PCR products from cDNA prepared to gill RNA from Penaeus monodon infected with LSNV. Sequencing of the 357 bp product showed $99.0 \%$ identity with LSNV detected in Thai P. monodon (Sritunyalucksana et al. 2006). To select the best tissue for screening different shrimp species for LSNV, various tissues from $P$. monodon and F. merguiensis including gill, pleopod, lymphoid organ, stomach, hepatopancreas, heart, nerve cord, brain, and optical lobe were tested. LSNV RNA amounts vary from tissue to tissue in both species, and whilst gill and pleopod showed relatively consistent PCR product yields, products were detected in nested PCR analyses of most other tissues (Fig. 1). Based on these data, gill and pleopod were employed as reference tissues to screen shrimp, whilst gill and stomach were used to screen crabs.

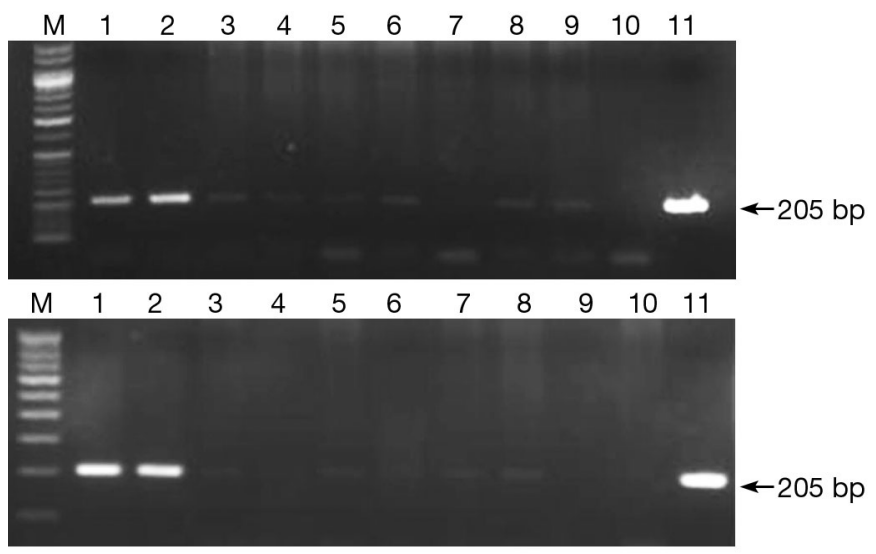

Fig. 1. RT-nested PCR amplification of Laem-Singh virus (LSNV) RNA from different tissues of Penaeus monodon (upper panel) and Fenneropenaeus merguiensis (lower panel). Lanes 1 to 9, respectively: gill, pleopod, lymphoid organ, hepatopancreas, stomach, heart, nerve cord, brain, optical nerve; Lane 10: negative control; Lane 11: positive control. Lane M: 100 bp DNA ladder

\section{Prevalence and host-range}

To examine the host-range and prevalence of LSNV in India, samples from various life stages of 6 penaeid shrimp species and of mud crab Scylla serrata were screened by RT-nested PCR. As shown in Table 1, LSNV was detected in Penaeus monodon, Fenneropenaeus merguiensis, Metapenaeus dobsoni, and Litopenaeus vannamei but not in F. indicus, Marsupenaeus japonicus or $S$. serrata. Among the LSNV-positive shrimp, the highest prevalence $(48.6 \%)$ occurred in farmed juvenile $P$. monodon, followed by $P$. monodon brooders $(20.0 \%)$ collected from the Andaman Sea. Among the 16 pools of $4 \mathrm{P}$. monodon postlarvae tested, 5 tested LSNV-positive by first-step PCR, and another 2 tested positive by nested PCR. LSNV RNA was detected by RT-nested PCR in $20.0 \%$ of juvenile $M$. dobsoni, $13.9 \%$ of juveniles, and 1 of 12 pools of $L$. vannamei postlarvae, and in $7.7 \%$ of juveniles and 2 of 10 pools of F. merguiensis postlarvae. Except for the 5 pools of $P$. monodon postlarvae that tested positive by PCR, LSNV RNA levels in all other positive samples required nested PCR for detection of an amplicon.

\section{Quantification of LSNV RNA in clinical samples}

Real-time qRT-PCR was used to quantify the LSNV RNA loads in samples of different life stages of penaeid shrimp species that tested positive by conventional RTnested PCR (Fig. 2). Amongst samples of juvenile shrimp, the highest RNA loads were evident in Penaeus monodon $\left(1.2 \times 10^{6}\right.$ copies $\left.\mu^{-1}\right)$ followed by Litopenaeus vannamei $\left(2.9 \times 10^{5}\right.$ copies $\left.\mu^{-1}\right)$, Meta- 
Table 1. RT-PCR screening of penaeid shrimps and mud crabs for Laem-Singh virus (LSNV) in India. (-): not available

\begin{tabular}{|c|c|c|c|c|c|c|c|}
\hline Stage & $\begin{array}{c}\text { Mean } \\
\text { length }(\mathrm{cm})\end{array}$ & $\begin{array}{c}\text { Mean } \\
\text { weight (g) }\end{array}$ & $\begin{array}{l}\text { Collection } \\
\text { location }\end{array}$ & $\begin{array}{c}\text { Tissue } \\
\text { screened }\end{array}$ & $\begin{array}{c}\text { No. of } \\
\text { animals tested }\end{array}$ & $\begin{array}{l}\text { LSNV-F } \\
\text { 1st-step }\end{array}$ & $\begin{array}{l}\text { RT-PCR } \\
\text { 2nd-step }\end{array}$ \\
\hline \multicolumn{8}{|c|}{ Penaeus monodon } \\
\hline Juveniles & 13.0 & 20.0 & Maharashtra & Gill and pleopod & 35 & 0 & 17 \\
\hline Brood stock & 23 & 110.0 & Andaman & Pleopod & 20 & 0 & 4 \\
\hline Postlarvae & - & - & Andhra Pradesh & Whole & 64 (16 pools) & 5 & 7 \\
\hline \multicolumn{8}{|c|}{ Fenneropenaeus merguiensis } \\
\hline Juveniles & 13.0 & 18.0 & Tamil Nadu & Whole & 13 & 0 & 1 \\
\hline Postlarvae & - & - & Tamil Nadu & Gill and pleopod & 40 (10 pools) & 0 & 2 \\
\hline \multicolumn{8}{|c|}{ Fenneropenaeus indicus } \\
\hline Juveniles & 9.0 & 9.5 & Tamil Nadu & Gill and pleopod & 22 & 0 & 0 \\
\hline Postlarvae & - & - & Tamil Nadu & Whole & 24 (6 pools) & 0 & 0 \\
\hline \multicolumn{8}{|c|}{ Litopenaeus vannamei } \\
\hline Juveniles & 14.0 & 17.0 & Andhra Pradesh & Gill and pleopod & 36 & 0 & 5 \\
\hline Postlarvae & - & - & Andhra Pradesh & Whole & 48 (12 pools) & 0 & 1 \\
\hline \multicolumn{8}{|c|}{ Marsupenaeus japonicus } \\
\hline \multicolumn{8}{|c|}{ Metapenaeus dobsoni } \\
\hline Juveniles & 11.0 & 12.0 & Tamil Nadu & Gill and pleopod & 15 & 0 & 3 \\
\hline \multicolumn{8}{|c|}{ Scylla serrata } \\
\hline Juveniles & - & 32.0 & Maharashtra & Gill and stomach & 10 & 0 & 0 \\
\hline
\end{tabular}

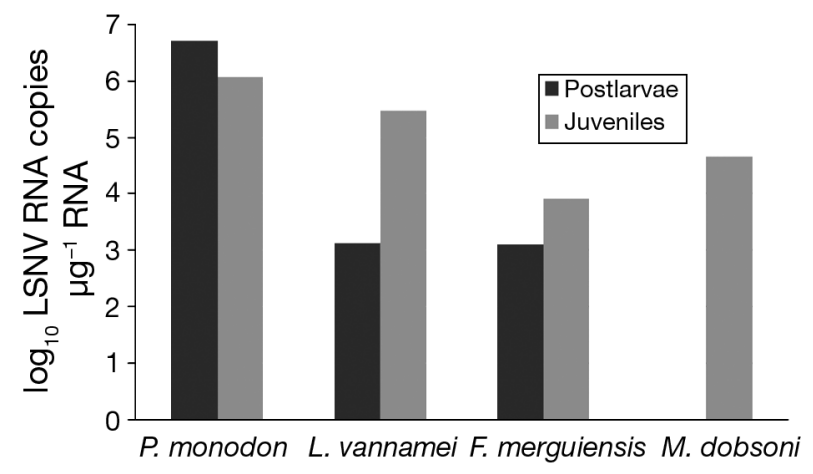

Fig. 2. Laem-Singh virus (LSNV) RNA copy number estimated in postlarvae and juveniles of different penaeid shrimp by real-time quantitative RT-PCR. See Table 1 for full species names

penaeus dobsoni $\left(4.7 \times 10^{4}\right.$ copies $\left.\mu^{-1}\right)$, and Fenneropenaeus merguiensis $\left(8.2 \times 10^{3}\right.$ copies $\left.\mu^{-1}\right)$. Among samples of postlarvae, the highest LSNV RNA loads were evident in $P$. monodon $\left(5.1 \times 10^{6}\right.$ copies $\left.\mu \mathrm{g}^{-1}\right)$, followed by $L$. vannamei $\left(1.3 \times 10^{3}\right.$ copies $\left.\mu \mathrm{g}^{-1}\right)$ and $F$. merguiensis $\left(1.2 \times 10^{3}\right.$ copies $\left.\mu \mathrm{g}^{-1}\right)$.

\section{Non-association of LSNV with slow growth in Penaeus monodon}

To investigate whether LSNV was associated with slow growth in Penaeus monodon, shrimp collected from a farm which held both slow-growing and normal shrimp in the same pond were screened by real-time qRT-PCR after $120 \mathrm{~d}$ of culture. Of 35 shrimp collected, 16 showed signs of slow growth $(8.7 \mathrm{~cm}$ mean length, $8.2 \mathrm{~g}$ mean weight) and $19 \mathrm{did}$ not $(16.5 \mathrm{~cm}$ mean length, $30.8 \mathrm{~g}$ mean weight). Of these, 10 (62.5\%) slow-growing shrimp and 7 (36.8\%) normal shrimp were positive by real-time qRT-PCR. No significant differences in LSNV RNA copy number were evident either between slow-growing and normal shrimp, or between infected and uninfected shrimp in their body length or weight (Table 2). The model $\mathrm{R}^{2}$ value was found to be 7.5 and $9.4 \%$ for weight and length, respectively.

\section{Experimental infection of Penaeus monodon and Scylla serrata with LSNV}

A virus inoculum was prepared from Penaeus monodon that were RT-PCR-positive for LSNV and PCRnegative for WSSV. RT-nested PCR analysis of RNA isolated from the inoculum generated no amplicon by 1-step PCR but a 205 bp amplicon by nested PCR.

In healthy LSNV-free Penaeus monodon (21 $\pm 3 \mathrm{~g})$ injected with inoculum and sacrificed at $48 \mathrm{~h}$ postinjection, LSNV was detected by RT-nested PCR in RNA extracted from gill, pleopod, lymphoid organ, nerve cord, and brain tissue but not optical lobe tissue. At Day 8 post-injection, LSNV infection loads were 
Table 2. Relation between body weight and length and LaemSingh virus (LSNV) infection (means \pm SE). Superscript letter indicates that means within a group show no significant difference $(p<0.05)$ from one another

\begin{tabular}{|lccc|}
\hline Status & $\begin{array}{c}\text { No. of } \\
\text { observations }\end{array}$ & $\begin{array}{c}\text { Weight } \\
(\mathrm{g})\end{array}$ & $\begin{array}{c}\text { Length } \\
(\mathrm{cm})\end{array}$ \\
\hline $\begin{array}{l}\text { Overall } \\
\text { Infection status }\end{array}$ & 35 & $15.03 \pm 1.14$ & $13.12 \pm 0.73$ \\
$\begin{array}{l}\text { Negative } \\
\text { Positive }\end{array}$ & 17 & $18.73^{\mathrm{a}} \pm 1.21$ & $14.47^{\mathrm{a}} \pm 1.02$ \\
& 18 & $12.06^{\mathrm{a}} \pm 1.21$ & $11.76^{\mathrm{a}} \pm 1.05$ \\
\hline
\end{tabular}
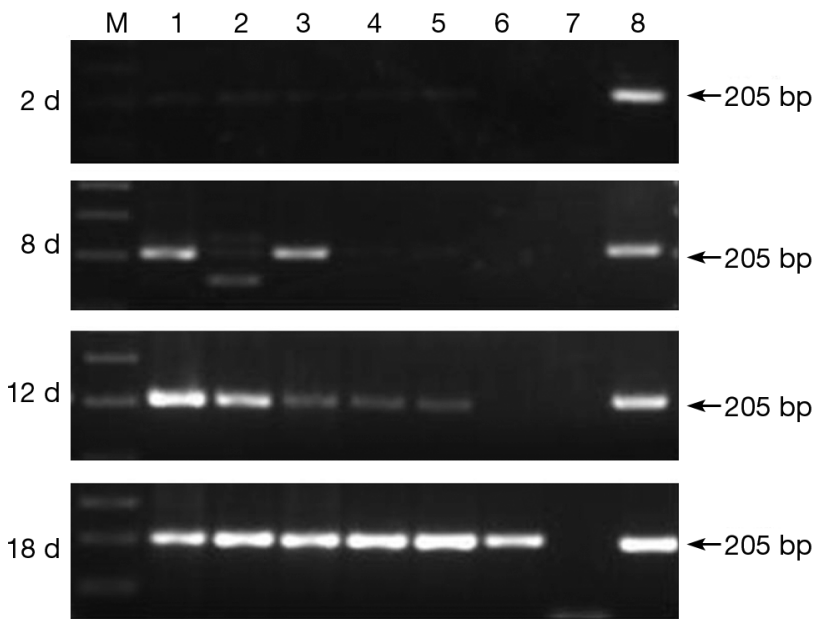

Fig. 3. RT-nested PCR of different tissues of Penaeus monodon infected experimentally with Laem-Singh virus (LSNV) collected at 4 time-points post-injection. Lanes 1 to 6, respectively: gill, pleopod, lymphoid organ, nerve cord, brain, optical lobe; Lane 7: negative control; Lane 8: positive control.

Lane M: 100 bp DNA ladder

increased noticeably in gill, pleopod, and lymphoid organ tissue, and increased progressively until Day 18 post-injection, except in optic lobe tissue (Fig. 3). Realtime qRT-PCR analysis of RNA extracted from gill was used to quantify the increases in LSNV infection loads over time post-injection (Fig. 4).

To examine the susceptibility of Scylla serrata to LSNV infection, the inoculum was injected into the coxa of the swimming leg, and crabs were sacrificed at 12 and $24 \mathrm{~h}$, and 8 and $20 \mathrm{~d}$ post-injection to collect gill and stomach tissue. RT-nested PCR only generated amplicons at the Day 8 and Day 20 post-injection sampling points (Fig. 5).

\section{LSNV sequence analysis}

Cloning and sequence analysis of 205 bp RT-nested PCR amplicon from LSNV-infected Penaeus monodon,

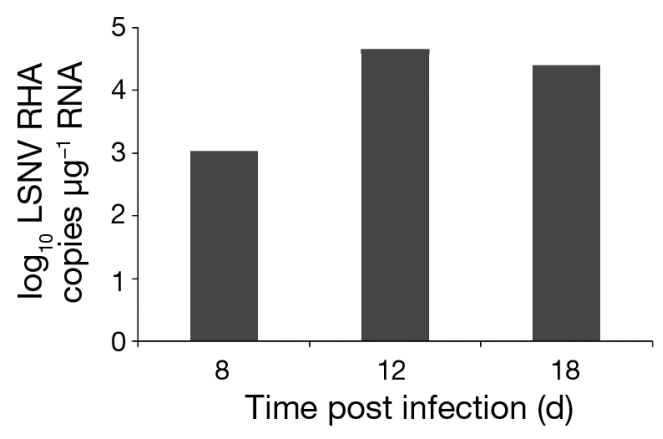

Fig. 4. Laem-Singh virus (LSNV) RNA copy number in gill tissue of experimentally-infected Penaeus monodon determined by real-time qRT-PCR

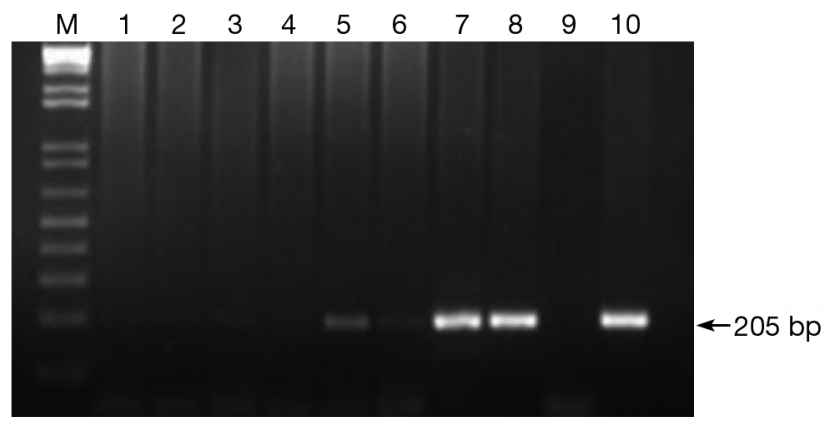

Fig. 5. RT-nested PCR amplification of Laem-Singh virus (LSNV) RNA from gill and stomach tissues Scylla serrata infected experimentally with LSNV collected at 4 time-points post-injection. Lanes 1 \& 2: $12 \mathrm{~h}$; Lanes 3 \& 4: $24 \mathrm{~h}$; Lanes 5 \& 6: $8 \mathrm{~d}$; Lanes 7 \& 8: $20 \mathrm{~d}$; Lane 9: negative control; Lane 10: positive control. Lane M: 100 bp DNA ladder

Fenneropenaeus merguiensis, Litopenaeus vannamei, and Metapenaeus dobsoni showed them to be identical (GenBank Accession no. HQ825248), except for F. merguiensis, which possessed a single $\mathrm{T} \rightarrow \mathrm{C}$ transition (alanine to valine change) and was identical to a LSNV sequence obtained from Thai $P$. monodon (GenBank Accession no. DQ127905). The 357 bp first-step RTPCR product amplified from $P$. monodon postlarvae (GenBank Accession no. HQ728430) possessed 99.0\% identity to the Thai LSNV sequence.

\section{DISCUSSION}

Whilst mainly detected in Penaeus monodon (Sritunyalucksana et al. 2006, Pratoomthai et al. 2008, Sittidilokratna et al. 2009), LSNV has also been detected in Thai Litopenaeus vannamei investigated for abdominal segment deformity disease (Sakaew et al. 2008). In India thus far, LSNV has been reported only in P. monodon (Prakasha et al. 2007, Rai et al. 
2009). Of the 6 shrimp species and mud crab species from India examined here, RT-nested PCR evidence of LSNV infection was found in P. monodon, Fenneropenaeus merguiensis, L. vannamei, and Metapenaeus dobsoni at all life stages tested but not in $F$. indicus, Marsupenaeus japonicus, or Scylla serrata. The data thus confirm the existence of LSNV infection in L. vannamei farmed in India and suggest for the first time that $F$. merguiensis and $M$. dobsoni are similarly susceptible to natural infection. The study also shows infection to occur in $P$. monodon collected $2 \mathrm{~km}$ off the coast of Betapur, Andaman and Nicobar Islands, a popular ground for broodstock collection. The high prevalence of LSNV detected amongst $P$. monodon and the comparatively higher infection loads detected indicate that this species is a primary host of LSNV. Whilst the present study helps define that other crustacean species of commercial relevance in India might be sources of LSNV infection, far more extensive surveys are needed to elucidate its range of natural hosts more thoroughly. With the exception of $P$. monodon postlarvae, no samples of any tissue type from $P$. monodon or any other shrimp or crab species examined possessed infection loads sufficiently high to be detected by RT-PCR without the use of nested PCR. This is suggestive of a high infection prevalence amongst $P$. monodon postlarvae, this life stage being highly susceptible to infection, and of the likelihood of their infections being transmitted vertically from brooders. The finding also suggests that it might be worthwhile screening batches of $P$. monodon postlarvae for LSNV before stocking of aquaculture ponds. As LSNV detected in L. vannamei postlarvae and cultured juveniles was identical in sequence across the 205 nt region amplified by RT-nested PCR to that amplified from $P$. monodon, it seems likely that $P$. monodon used for aquaculture purposes might be the source of these infections, although additional studies are needed to confirm this.

The 357 nt region of the LSNV RNA genome amplified by RT-PCR from Penaeus monodon postlarvae displayed $99.0 \%$ nucleotide sequence identity to isolates detected in Thai P. monodon. These data support the findings of Sittidilokratna et al. (2009) that the extent of genetic variation in LSNV across India and southeast Asia is relatively low (>98\%).

Gill, pleopod, and lymphoid organ have been commonly used for RT-PCR screening for LSNV (Sritunyalucksana et al. 2006, Prakasha et al. 2007, Sittidilokratna et al. 2009). Study of the tissue tropism of LSNV has also shown infection to occur throughout neural tissues such as the thoracic ganglion, abdominal ganglion, brain, and optical lobe (Pratoomthai et al. 2008). Of several tissue types of the various shrimp species examined here, gill and pleopod generated the most consistent RT-nested PCR products amongst LSNV-infected Penaeus monodon and Fenneropenaeus merguiensis.

MSGS in farmed Penaeus monodon is a serious problem and has reduced the farm profitability and damaged export industries based on this species (Chayaburakul et al. 2004, Sritunyalucksana et al. 2006, Pratoomthai et al. 2008). In severe occurrences in Thailand, MSGS could result in up to $30 \%$ of pond stocks of $P$. monodon averaging only $6 \mathrm{~g}$ in weight after 4 months of culture, with unaffected shrimp averaging $30 \mathrm{~g}$ in weight (Withyachumnarnkul 2005). P. monodon farmed in India often also display lengths and body weights 2- and 4-fold lower, respectively, and appear more darkly colored than normal shrimp in the same pond $120 \mathrm{~d}$ after stocking. Unlike occurrences of MSGS in Thailand, however, unusually bright yellow markings, 'bamboo-shaped' abdominal segments, or brittle antennae have not been evident in smaller shrimp at farms in India. Real-time qRTPCR data showing no significant differences in LSNV infection loads in small and normal-sized P. monodon are consistent with it occurring in both MSGS affected and unaffected $P$. monodon in Thailand (Sritunyalucksana et al. 2006, Pratoomthai et al. 2008), indicating that other factors are needed to induce MSGS.

It has been reported that slow growth syndrome in Penaeus monodon can be induced when lymphoid organ extracts of MSGS-affected shrimp are injected into healthy P. monodon (Withyachumnarnkul 2005). However, no experimental LSNV infections have thus far been reported in any crustacean species in which increases in LSNV infection loads have been tracked. Such transmissions were undertaken here with LSNV RNA levels tracked by RT-nested PCR and real-time qRT-PCR. In $P$. monodon, although LSNV infection loads increased between 2 and $18 \mathrm{~d}$ post-injection, they did not reach levels sufficient for detection by RT-PCR without the use of nested PCR. Experimental LSNV infection of the mud crab Scylla serrata also induced gradual increases in viral load between $12 \mathrm{~h}$ and $8 \mathrm{~d}$ post-injection, after which time loads appeared to stabilize until $20 \mathrm{~d}$ post-infection. Whilst infection loads remained below the threshold needed for detection by RT-PCR without the use of nested PCR, and LSNV could not be detected in wild S. serrata collected from Maharashtra, the ability of LSNV to cause infection when injected into a crustacean species other than shrimp suggests that this and other species might be potential natural carriers of LSNV infection. As the data presented here indicate that the host-range of LSNV could involve crustacean species other than shrimp, this hypothesis warrants more thorough examination. 
Acknowledgements. The authors are grateful to the Director of the Central Institute of Fisheries Education (CIFE), Mumbai, for enabling us to use the Institute's facilities. We also thank Pancham Aqua, Maharashtra, Dr. G. Venugopal, and Dr. Suresh Babu, Kakinada Centre of CIFE, and Dr. Cp. Balasubramanian, Central Institute of Brackishwater Aquaculture, Chennai, for helping us to collect the samples. We gratefully acknowledge the help of Dr. S. S. Jahageerdar, CIFE, with statistical analysis.

\section{LITERATURE CITED}

Anantasomboon G, Sriurairatana S, Flegel TW, Withyachumnarnkul B (2006) Unique lesions and viral-like particles found in growth retarded black tiger shrimp Penaeus monodon from East Africa. Aquaculture 253:197-203

Chayaburakul K, Nash G, Pratanpipat P, Sriurairatana S, Withyachumnarnkul B (2004) Multiple pathogens found in growth-retarded black tiger shrimp Penaeus monodon cultivated in Thailand. Dis Aquat Org 60:89-96

Lightner DV (1996) A handbook of pathology and diagnostic procedures for diseases of penaeid shrimp. World Aquaculture Society, Baton Rouge, LA

Lightner DV, Redman RM (1998) Shrimp diseases and current diagnostic methods. Aquaculture 164:201-220

Loh PC, Tapay LM, Lu Y, Nadala EC (1997) Viral pathogens of the penaeid shrimp. Adv Virus Res 48:263-312

Prakasha BK, Ramakrishna RP, Karunasagar I, Karunasagar I (2007) Detection of Laem-Singh virus (LSNV) in cultured Penaeus monodon from India. Dis Aquat Org 77:83-86

Editorial responsibility: Jeff Cowley, Brisbane, Queensland, Australia
Pratoomthai B, Waraporn S, Sriuairatanna S, Wongprasert K, Withyachumnarnkul B (2008) Retinopathy in stunted black tiger shrimp Penaeus monodon and possible association with Laem-Singh virus (LSNV). Aquaculture 284: $53-58$

Rai P, Pradeep B, Karunasagar I, Karunasagar I (2009) Detection of viruses in Penaeus monodon from India showing signs of slow growth syndrome. Aquaculture 289:231-235

Sakaew W, Pratoomthai B, Anantasomboon G, Asuvapongpatana S, Sriurairattana S, Withyachumnarnkul B (2008) Abdominal segment deformity disease (ASDD) of the white leg shrimp Penaeus vannamei reared in Thailand. Aquaculture 284:46-52

Sittidilokratna N, Dangtip S, Sritunyalucksana K, Babu R and others (2009) Detection of Laem-Singh virus in cultured Penaeus monodon shrimp from several sites in the IndoPacific region. Dis Aquat Org 84:195-200

Sritunyalucksana K, Apisawetakan S, Boon-nat A, Withyachumnarnkul B, Flegel TW (2006) A new RNA virus found in black tiger shrimp Penaeus monodon from Thailand. Virus Res 118:31-38

Umesha KR, Chakraborty A, Venugopal MN, Nagarajappa M, Karunasagar I (2008) Occurrence of multiple viruses in Penaeus monodon shrimp ponds and their effects on shrimp production. In: Bondad-Reantaso MG, Mohan CV, Crumlish M, Subasinghe RP (eds) Diseases in Asian aquaculture, Vol 6. Fish health section, Asian Fisheries Society, Manila, p 389-398

Withyachumnarnkul B (2005) Search for solutions for MSGS in farmed black tiger shrimp. AQUA Cult Asia Pac Mag 1: $14-15$

Submitted: December 24, 2010; Accepted: May 18, 2011

Proofs received from author(s): July 11, 2011 